This article was downloaded by: [University of Sussex Library]

On: 02 February 2015, At: 01:14

Publisher: Routledge

Informa Ltd Registered in England and Wales Registered Number: 1072954

Registered office: Mortimer House, 37-41 Mortimer Street, London W1T

3J H, UK

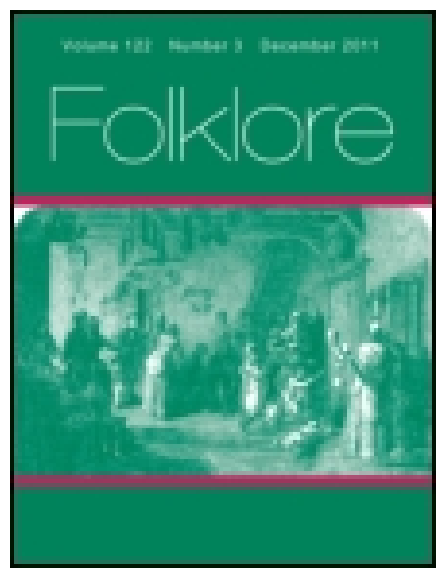

\title{
Folklore
}

Publication details, including instructions for authors and subscription information:

http:// www. tandfonline.com/loi/ rfol20

\section{Forty-First Annual Report of the Council.}

A. C. Haddon

Published online: 01 Feb 2012.

To cite this article: A. C. Haddon (1919) Forty-First Annual Report of the Council., Folklore, 30:1, 4-9, DOI: 10.1080/0015587X.1919.9719075

To link to this article: http:// dx. doi. org/ 10.1080/0015587X.1919.9719075

\section{PLEASE SCROLL DOWN FOR ARTICLE}

Taylor \& Francis makes every effort to ensure the accuracy of all the information (the "Content") contained in the publications on our platform. However, Taylor \& Francis, our agents, and our licensors make no representations or warranties whatsoever as to the accuracy, completeness, or suitability for any purpose of the Content. Any opinions and views expressed in this publication are the opinions and views of the authors, and are not the views of or endorsed by Taylor \& Francis. The accuracy of the Content should not be relied upon and should be independently verified with primary sources of information. Taylor and Francis shall not be liable for any losses, actions, claims, proceedings, demands, costs, expenses, damages, and other liabilities whatsoever or howsoever caused arising directly or indirectly in connection with, in relation to or arising out of the use of the Content.

This article may be used for research, teaching, and private study purposes. Any substantial or systematic reproduction, redistribution, reselling, loan, sub-licensing, systematic supply, or distribution in any form to anyone is 
expressly forbidden. Terms $\&$ Conditions of access and use can be found at http://www.tandfonline.com/page/terms-and-conditions 


\section{FORTY-FIRST ANNUAL REPORT OF THE COUNCIL.}

Notwithstanding the increasing difficulties caused by the long duration of the war, the Society has continued to hold its meetings during the past year, and generally they have been well attended.

Sixteen new members have been enrolled during the year, and three libraries have been added to the list of subscribers. On the other side of the account there have been nine deaths and twenty resignations, so that the members of the Society are diminished by ten, and there are now only 394 members and subscribers on the roll as against 404 a year ago.

Among the members who have died are Dr. Walker, Miss S. Morison, and Mr. Thurstan Peter, who was one of the very few representatives of the Society in the west country, where it is to be hoped that it may be more fully represented in the future than at present.

Considering the many and various calls the war has made on the energies of the country, the Council think the Society is to be congratulated on having kept its numbers at so high a level: and now that peace is well in sight, they hope that before they issue their next. Annual Report the Society will be as flourishing as it was in its palmiest days.

The amount received in subscriptions during the year was $£ 386$ 8s. Od., which was $£ 13$ more than in 1917 ; and of this amount a larger proportion even than a year ago represented arrears. 
Meetings of the Society have been held as follows, viz. :$23 \%$ January. "The Influence of Burial Customs on the Belief in a Future State." Mrs. Iolland.

20th February. (Annual Meeling,) Presidential Address: "The Transvaluation of Culture." Dr. R. R. Marett.

20th March. "The House in India in its Sociological and Folklore Aspects." Mr. IV. Crooke.

17th Aprit. "Magic and Religion." Mr. N. W. Thomas.

15th May. "Some Mythical Tales of the Lapps." Mr. C. J. Billson; and

"The Medioval Legend of the Terrestrial Paradise." Mr. M. Esposito.

19th June. "Further Studies in Irish Folk-lore." Miss Moutray Lead,

20th November. "The Rosary in Magic and Religion." Miss Blackman.

Miss Blackman's paper was profusely illustrated by lantern slides, and elicited an interesting discussion. $\mathrm{Mr}$. A. R. Wright at the same meeting exhibited a collection of rosaries, and Miss Burne a rosary picked up by a soldier on the battlefield of Tel-el-Kebir.

The Council regret that so few objects of folklore interest have been exhibited during the year, and they venture to express the hope that members and friends will not hesitate to bring with them to the meetings any objects illustrative of the papers announced to be read.

Several additions have been made to the Society's library during the year, particulars of which have been duly noted in. Folk-Lore. Members are reminded that they may borrow books from the library, which is housed at University College, subject to the regulations laid down by the Council, particulars of which may be obtained on application to Dr. R. W. Chambers, the Hon. Librarian at the College.

The twenty-ninth volume of Folk-Lore has been issued during the year. The cost of paper and labour has again considerably increased, and the Council have in consequence found it necessary further to reduce the size of the volume, and to dispense with illustrations. Even so, the cost of the volume is more than double what it was in pre-war days: In these circumstances the Council have been reluctantly compelled to defer the issue of any additional volume for 
the present. A year hence they will be in a position to take stock of the financial position of the Society, and should the cost of paper and printing be sensibly diminished it is possible that they may be able to issue an additional volume in 1920 . They fear, however, that they may by that time have lost the opportunity of publishing several MSS. which have been offered to them.

Owing to the regrettable illness of Miss Burne, who has succeeded Dr. Wheatley as Editor-in-Chief of the material in course of collection for a new edition of Brand's calendar customs of Brand's Popular Antiquities, there is no report to hand from the Brand Committee. The Council, however, are pleased to announce that they have received a generous contribution of $\epsilon_{20}$ from an anonymous donor for the work of the Committee, and they have reason to know that a considerable amount of spadework has been done during the year. It is feared that Miss Burne's illness will prevent her resuming the direction of the work, but the Committee are making arrangements for carrying it on with as little dislocation as possible. The Council wish to place on record their profound appreciation of Miss Burne's services, and their most sincere regret that she feels at present unable to complete the task into which she had thrown such unstinted energy and enthusiasm.

The sales of the Society's publications for the year I9I7 amounted to $£ 2515 \mathrm{~s} .7 \mathrm{~d}$. only. In view of the disorganisa. tion caused by the war, no larger return cquld reasonably have been expected. Both Mr. Sidgwick and Mr. Jackson have been on active service throughout the year, and no account of the sales of the Society's publications in 1918 is yet available. There is no reason, however, to expect that they will fall short of those in the previous year.

$A$ sum of $£ 30$ has bcen received on account of the sales of salvage stock. A large number of volumes, however, still remain unsold, and may be inspected by intending purchasers at Messrs. H. F. Fayers \& Co.'s warehouse, 
Bishop's Court, Old Bailey, E.C., where they are stored. Mr. C. J. Tabor, of the White House, Knotts Green, Essex, has kindly undertaken to be responsible for their sale. The price is $4 s$. per volume, with all faults, carriage paid. In order to effect further economies the Council omitted the meeting in December, and decided not to provide tea before the meetings. But after the end of the present session it is hoped that the old order of things may be restored.

The Cash Account and Balance Sheet for the year are submitted herewith.
A. C. HADDON,
Presilkent. 


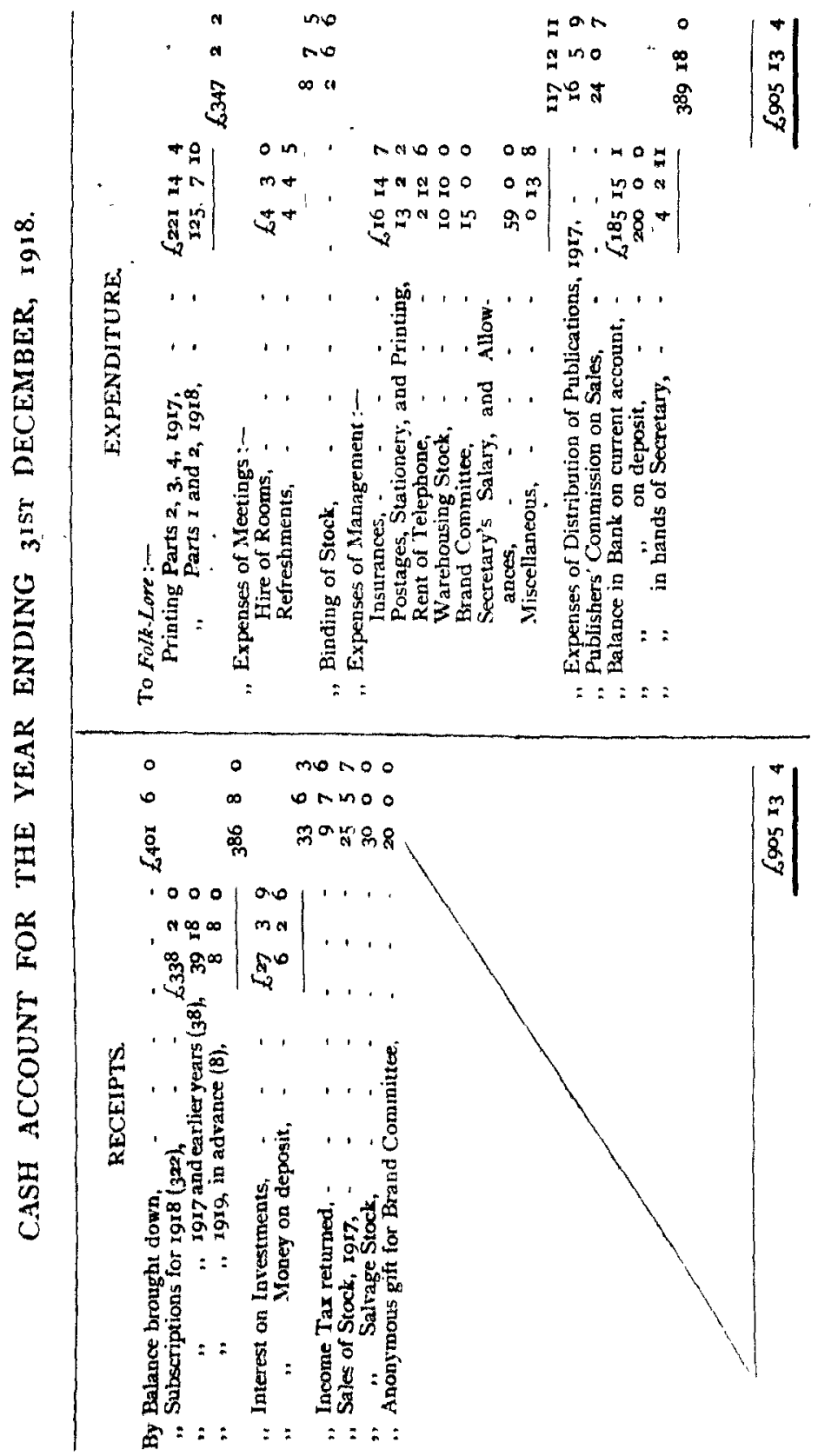




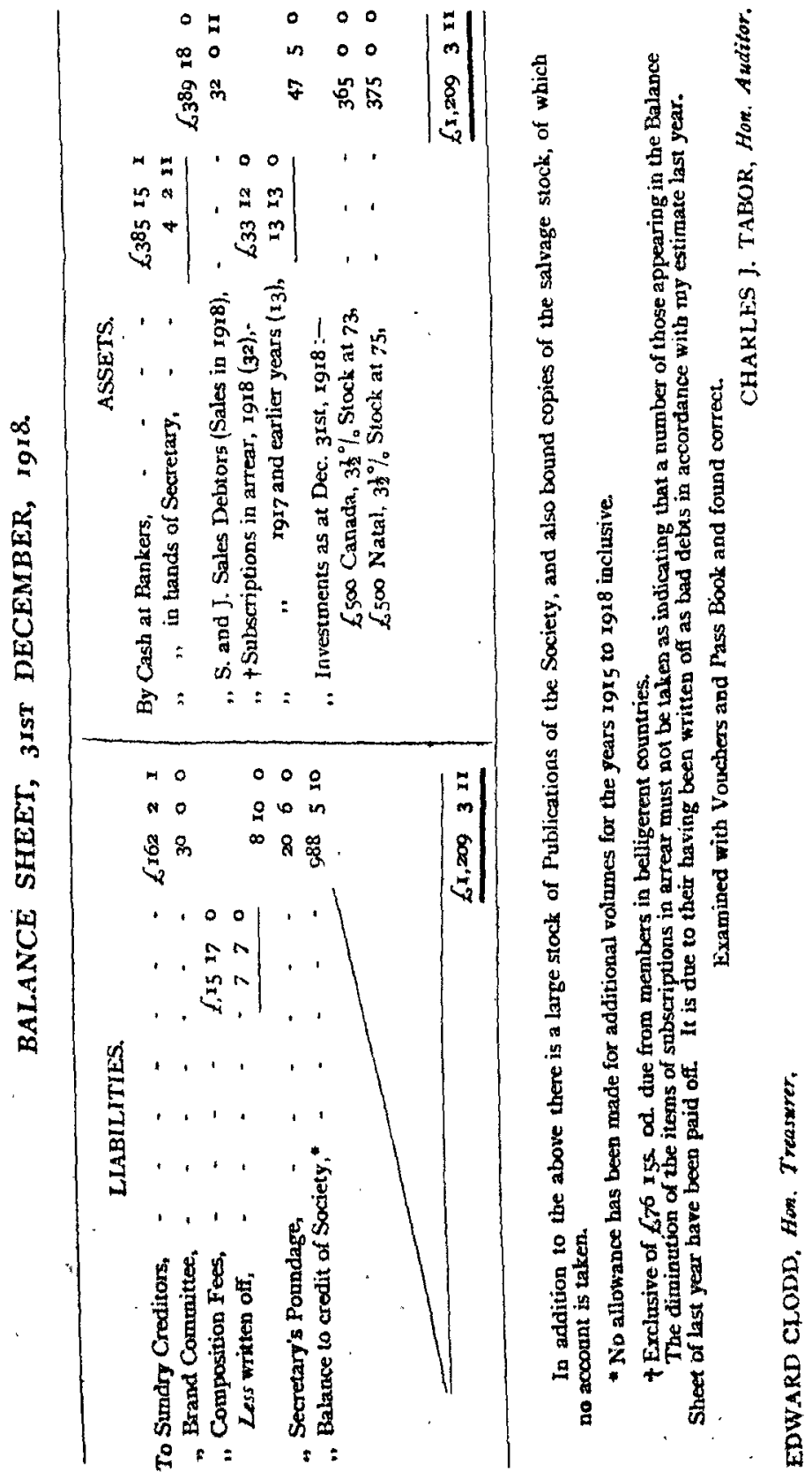

